\title{
Effect of Cassava Starch Sources on Growth and Feed Utilization of Nile Tilapia Fingerlings (Oreochromis niloticus) Reared Under Two Dietary Protein Levels
}

\author{
Dulmini Mahanama $^{1}\left({ }^{D}\right.$, Kumudu Radampola $^{1, *}\left(\mathbb{D}\right.$, Erangi Heenkenda $^{1}$
}

\begin{abstract}
${ }^{1}$ University of Ruhuna, Faculty of Fisheries and Marine Sciences \& Technology, Department of Fisheries and Aquaculture, Sri Lanka.
\end{abstract}

\begin{abstract}
How to cite
Mahanama, D., Radampola, K., Heenkenda, E. (2021). Effect of Cassava Starch Sources on Growth and Feed Utilization of Nile Tilapia Fingerlings (Oreochromis niloticus) Reared Under Two Dietary Protein Levels. Aquaculture Studies, 21, 169-179. https://doi.org/10.4194/2618-6381-v21_4_04
\end{abstract}

\section{Article History}

Received 26 January 2020

Accepted 05 August 2021

First Online 08 August 2021

Corresponding Author

Tel.: +940712303552

E-mail: kumudu@fish.ruh.ac.lk

\section{Keywords}

Cassava Starch

Protein

Nile Tilapia

Growth Performance

Feed Utilization

\begin{abstract}
A 42-day experiment was performed to evaluate the growth performance and feed utilization of Nile tilapia (Oreochromis niloticus) fingerlings fed iso-lipidic diets (5\% lipid) contain $17 \%$ or $25 \%$ of cassava starch extract from fresh root ( $R$ starch) or from dry chips (D-starch) at $37 \%$ and $30 \%$ protein levels. The diets were ie: $37 \%$ protein $\mathrm{FM}_{25} \mathrm{R}_{17}$ \& $\mathrm{FM}_{25} \mathrm{D}_{17}, 30 \%$ Protein- $\mathrm{FM}_{15} \mathrm{R}_{25}$ \& $\mathrm{FM}_{15} \mathrm{D}_{25} .144$ fish $(1.11 \pm 0.02 \mathrm{~g})$ were distributed in 12 tanks $(54 \mathrm{~L})$. Protein level or starch source had no impact on final weight, length, average daily gain, specific growth rate, food conversion ratio, hepato somatic index, viscero somatic index, and Whole-body composition of fish. Protein Efficiency Ratio was not affected by starch source; however, it was significantly higher in diets with low protein content. Apparent Digestibility Coefficient of dry matter was not affected by starch source but was significantly high in low (30\%) protein diet. Inclusion of R starch substantially reduced the cost of feed and increased economic profitability. Tilapia fed $\mathrm{FM}_{15} \mathrm{R}_{25}$ diet showed similar growth and nutrient utilization to fish fed $37 \%$ protein diets and cost of $\mathrm{FM}_{15} \mathrm{R}_{25}$ diet was lower than other diets. Therefore, $\mathrm{FM}_{15} \mathrm{R}_{25}$ is the best practical diet among the tested diets for Nile tilapia fingerlings.
\end{abstract}

\section{Introduction}

Global food fish aquaculture is playing a significant role in providing sufficient amount of food fish for world's growing population (FAO, 2018). Asian countries dominated in aquaculture production and produced $89.4 \%$ of world aquaculture production (FAO, 2018). Fish require high amount of high quality protein for best growth and maintenance compared to terrestrial animals (Wee and $\mathrm{Ng}, 1986$ ). Protein is the most expensive nutrient in the fish feed production, which contributes to the major part of the total feed cost
(Rahman et al., 2017) and fish meal is the major protein source in fish feed preparation. Therefore, exploring various ways to reduce feed cost by using alternative nutrient sources to limit the use of fish meal in diet preparation is a major concern in fish nutrition research (Wang et al., 2017). Further, utilizing the proteinsparing action of carbohydrates or lipid is another option to reduce the amount of fish meal required in fish feed formulation (Wee and $\mathrm{Ng}, 1986$ ). Non-protein nutrients such as lipids and carbohydrates have protein sparing potential in diets (Stone et al, 2003). Lipids are excellent as an energy source but they are expensive 
than the plant carbohydrates. Therefore, carbohydrate sources can be used to spare protein especially in omnivorous fish as they can utilize more carbohydrates than other carnivore fish (Stone et al, 2003). Carbohydrates can be included at optimum levels in aquaculture diets to reduce feed costs and also as a binder during feed manufacturing (Fayose and Ogunlowo, 2012). Further starches and sugars are the most economical and inexpensive source of energy for fish diets (Shiau and Peng, 1993).

Cassava (Manihot esculanta) is a rich carbohydrate source and starch extracted from cassava roots is a cheap, highly available non-protein energy source, which has been tested as a fish feed ingredient in many studies (Wee and Ng, 1986; Ubalua and Ezeronye, 2008, Breuninger et al, 2009). However, cassava was not very popular as an ingredient of fish diet due to the high cyanide content (Montagnac et al, 2009). Cyanide in Cassava can be found as bound glucosides, cyanohydrins, and free cyanide. Extracted starch from the fresh root, are grated and ground with water and the cyanide will be dissolved in supernatant water. Extracted starch from dry chips are processed using mechanical drying, such as in an oven, and natural drying by the sun (Oke, 1994). Toxicity of the cyanide in Cassava can be removed through different processing methods, used for the starch extraction (Montagnac et al, 2009). Some studies were carried out to study the feasibility of using cassava starch as a feed ingredient in order to enhance the growth performance and the survival of cultured fish species. Wee and Tuan, (1988) recorded that when Oreochromis niloticus fed with five diets containing five levels of protein $(20 \%, 28 \%, 35 \%$, $43 \%, 50 \%)$ and Cassava starch (51.4\%, 39.8\%, 27.7\%, $16.1 \%, 3.6 \%)$ the highest growth was obtained by fish fed diet containing 35\% dietary protein level and $27.7 \%$ cassava starch. They have concluded that, fish were progressively improving growth response with increasing dietary protein levels up to $35 \%$ crude protein. In another study Cyprinus carpio fingerlings were fed with isonitrogenic diets containing 15\%, 30\% or $45 \%$ of cassava and a control diet that did not contain any digestible carbohydrates for 10 weeks (Ufodike and Matty,1983) and fish grew best in the diet contained $45 \%$ cassava, $30 \%$ fishmeal compared to the control diet having $0 \%$ cassava and $30 \%$ fish meal.

Cassava is a very common locally available food ingredient in Sri Lanka and cassava fresh root can be obtained at a very cheap price in the local markets. Furthermore, surplus in production during the harvesting period, causes very low demand for the cassava production and becomes an unutilized food source Cassava starch can be extracted using both fresh roots and dry chips (Meuser et al, 1978). Purity of the starch varies with the source and the purest starch was extracted from the fresh roots compared to dry chips (Meuser et al, 1978). Cassava starch is comparatively low price ingredient and incorporation of cassava starch may reduce the production cost of fish feed.
Nile tilapia considered as the second most cultured fish after carp, which are farmed in over 100 countries (FAO, 2019). As the market price for tilapia is low, to achieve a least-cost production for global demand, research has been focused on the formulation of a cost effective feed for tilapia farming, incorporating high levels of dietary carbohydrates (Boonanuntanasarn et al., 2018). Nile Tilapia can utilize high amount of carbohydrate (up to $27.7 \%$ ) and different carbohydrate sources, such as starch, glucose and dextrin (Wee and Tuan, 1988; Shiau and Peng, 1993; Boonanuntanasarn et al, 2018). Tilapia pond culture has been widely practice in Sri Lanka at present with the support of the National Aquaculture Development Authority of Sri Lanka (Amarasinghe, 2013). Many farmers in rural areas culture tilapia as small scale aquaculture practice and, the lack of suitable feed is a major concern of these farmers. Hence, developing low cost feeds for tilapia will help to develop sustainable culture (Amarasinghe, 2013). The present study will focus on using cassava starch as a low cost ingredient in tilapia feeds.

During the harvesting period, a major problem of cassava production is the rapid postharvest deterioration of casava roots which usually prevents their storage in the fresh state for more than a few days (Somendrika et al, 2016). Therefore, large amount of harvested cassava roots is wasted without consuming. However, if farmers can produce starch from their excess cassava harvest which cannot be marketable, it can be a better way to utilize this unutilized resource and they will be able to obtain some extra profit from their wasted harvest.

However, there is no sufficient information in the literature on using cassava starch as a fish feed ingredient in Sri Lanka. Although cassava starch is a cheap feed ingredient, yet it is not used in small scale pond culture in Sri Lanka. Therefore, the specific aim of the present study was to evaluate the effect of varying levels $(17 \%, 25 \%)$ of two starch sources (extracted from fresh root or dry chips) at two dietary protein levels (37\% and $30 \%$ ) in diets on growth performance and feed utilization of Nile tilapia fingerlings and to determine the cost effectiveness of the experimental diets.

\section{Materials and Methods}

\section{Experimental Design}

Nile tilapia fingerlings $(4.03 \pm 0.01 \mathrm{~cm}, 1.11 \pm 0.02 \mathrm{~g})$ were purchased from Muruthawela NAQDA center and brought to the aquarium of Faculty of Fisheries and Marine Sciences \& Technology of University of Ruhuna. They were acclimatized for two days and randomly distributed among the twelve rectangular glass tanks $(60 \mathrm{~cm} \times 30 \mathrm{~cm} \times 30 \mathrm{~cm})$ at a stocking density of 12 fry/tank. Each treatment had 3 replicates. Tanks were filled with dechlorinated water ( $45 \mathrm{~L}$ ) and aerated using mechanical aerators and natural photoperiod was used during the experimental period. 


\section{Preparation of Starch Extract from Fresh Cassava Roots}

Starch was extracted using fresh cassava roots using following procedure. Fresh cassava roots were peeled, washed and grated. Two liters of water was added to $1 \mathrm{~kg}$ of grated cassava and ground using a high speed blender (Preethi MG $176600 \mathrm{~W}$ ) for 10 minutes. The pulp was filtered using a double folded cotton cloth. The filtrate was allowed to stand for $2 \mathrm{hrs}$ to settle starch and top supernatant was removed. $200 \mathrm{ml}$ of water was added to the sediment and stirred again for 5 minutes and filtered. This process was repeated three times to remove impurities and after decanting the supernatant, final sediment layer was dried in sun light for 72 hours. Then dried starch was crushed, sieved and stored in a refrigerator at $-20^{\circ} \mathrm{C}$ ((Abera and Rakshit, 2003).

\section{Preparation of Starch Extract from Dry Cassava Chips}

Starch was extracted using dry cassava chips using following procedure. Grated fresh cassava were sun dried for 3 days to prepare dry chips and ground using a high speed blender and then flour was mixed with water. The pulp was filtered and the sediment layer was collected and dried according to the previous procedure. Finally, the dried starch layer was crushed, sieved and stored in a refrigerator at $-20^{\circ} \mathrm{C}$ (Abera and Rakshit, 2003).

\section{Feed Preparation}

Four experimental diets were formulated to contain one of two protein levels $(37 \%, 30 \%)$ by altering the carbohydrate level using two different starch extractions ( $R$ starch -extract from cassava fresh root or D starch - extract from dry cassava chips) (Table 1). The dry ingredients were finely ground and sieved through a $1 / 100$-inch sieved and mixed thoroughly. Warm water $\left(20^{\circ} \mathrm{C}\right)$ was added $(25 \%)$ slowly to the mixture with continuous stirring until a dough was formed. The dough was steamed for 15 minutes and pelleted using a hand pelleting machine. Extruded pellets ( $4 \mathrm{~mm}$ diameter) were oven-dried at $60^{\circ} \mathrm{C}$ for $12 \mathrm{hrs}$, stored in plastic bags and kept at $-20^{\circ} \mathrm{C}$ in the freezer.

\section{Experimental Procedure}

The fish were hand fed with respective diet to satiation at 08:00 a.m and 04:00 p.m. during the experimental period. The fecal matter was siphoned out daily before feeding the fish and optimum aeration was supplied. Tanks were cleaned and $1 / 3$ of water removed by siphoning at two-day intervals and refilled using dechlorinated water. Dissolved oxygen was measured once a week using a water quality meter (PRO2030). Nitrite, nitrate and ammonia were measured once a week using a laboratory test kit (ZOOLEK). Temperature was measured daily using a thermometer and $\mathrm{pH}$ was measured once a week using a pH meter (EUTECH pH6).
Length and weight of individual fish at the beginning of the experiment and at fortnightly intervals were taken using a measuring board $(1 \mathrm{~mm})$ and an electronic balance $(0.01 \mathrm{~g})$ respectively. Fish were sacrificed at the end of the growth trail and liver and viscera were removed. Average Daily Weight Gain (ADG). Percentage Specific Growth Rate (SGR) Hepatosomatic Index (HSI) and Viscerosomatic Index (VSI), Food consumption (\% Bwt/day), Feed conversion ratio (FCR) Protein efficiency ratio (PER) and condition factor were used to evaluate the growth performance and feed utilization of tilapia fry (Ricker, 1979).

Feed ingredients, experimental diets and fish carcasses were analyzed for proximate composition using the standard methods (AOAC, 1990). Moisture content was determined by using drying method, using an oven at $105^{\circ} \mathrm{C}$. Crude protein content was determined by using Kjeldahl method. Ash content was determined by using combustion method, using a muffle furnace at $550^{\circ} \mathrm{C}$. Crude lipid content was determined by using procedure introduced by Folch (1957).

\section{Fecal Collection and Digestibility Analysis}

Feces were collected by siphoning water using a rubber hose (5mm diameter) on to a hand net and the collected feces were dried to a constant weight in the oven at $50^{\circ} \mathrm{C}$ and stored in bottles. In each tank dried fecal samples were pooled and subjected for the digestibility analysis. The apparent digestibility coefficient (ADC) was calculated for dry matter (Furukawa and Tsukahara, 1966).

\section{Economic Analysis of Diets}

The economic evaluation determined using the following indices (Agbo, 2008).

$$
\begin{gathered}
\text { Incidence of cost }=\frac{\text { Cost of feed (Rs) }}{\text { Weight of fish produced (g) }} \\
\text { Profit index }=\frac{\text { Value of fish (Rs) }}{\text { Cost of feed (Rs) }}
\end{gathered}
$$

\section{Water Quality Analysis}

Dissolved oxygen was measured once a week using a water quality meter (PRO2030). Nitrite, nitrate \& ammonia were measured once a week using a laboratory test kit (ZOOLEK). Temperature was measured daily using a thermometer and $\mathrm{pH}$ was measured once a week using a pH meter (EUTECH pH6).

\section{Statistical Analysis}

All the statistical analyses were accomplished with the SPSS statistical package (IBM SPSS Statistics 25.0). Data was presented as means with the standard error. All the data were analyzed by two-way ANOVA to test 
for effect of protein level or effect of starch source or interaction of two factors on the growth and feed performance of fish $(\mathrm{P}<0.05)$.

\section{Results}

\section{Growth Performance and Feed Utilization}

Nile tilapia fingerlings accepted all experimental diets and did not show any abnormal behaviors or symptoms during the experimental period. The water quality parameters in the tank water were not different among the treatments and not influenced by the dietary protein level and starch source. Fish in all treatments showed good survival and there was no difference of survival rate between the treatments (Table 2).

The total length and weight of fingerlings increased two fold and nine fold over six weeks period respectively (Table 2). Final weight varied from $1.09 \pm 0.02$ to $1.14 \pm 0.04 \mathrm{~g}$ not affected by the protein level or starch source (Figure 1 and 2). ADG, SGR, HSI, VSI and condition factor of fish in different treatments were not affected by the protein level or starch extraction method. Mean daily food consumption (\%BW/day) $(9.92 \pm 0.43$ to $11.09 \pm 0.35)$ were not significantly different among treatments $(P>0.05)$ and not affected by dietary protein level or extraction method of starch.

Food conversion ratio $(1.45 \pm 0.05$ to $1.65 \pm 0.03)$ were not affected by dietary protein level or starch extraction method and no interaction effect was observed. However, Protein efficiency ratio (PER) of Nile tilapia fingerling was varied within $1.5 \pm 0.04$ to $2.31 \pm 0.07$ and the PER was influenced by the dietary protein level. High dietary protein level resulted a lower PER in diet and low dietary protein level resulted a higher PER. However, the starch extraction method had no impact on PER and there was no interaction effect between dietary protein level and starch source on PER.
Apparent digestibility coefficient (ADC) of dry matter was significantly affected $(P<0.05)$ by the level of dietary protein (Table 3). ADC of dry matter was higher at the low dietary protein level (30\%) compared to high dietary protein (37\%) level. However, the extraction method of starch (Fresh or Dry) had no impact on ADC of dry matter. At the end of the growth trial, the protein, lipid, ash and moisture contents of fish carcasses were not significantly different among treatments, and no significant effect of inclusion level of starch or source were observed (Table 4).

\section{Water Quality}

The mean water quality parameters obtained in the experimental tanks did not vary significantly $(P>0.05)$ and were not influenced by the dietary protein level and starch source (Table 5). All were within the suggested tolerance ranges.

\section{Cost Analysis}

The preparation costs for experimental diets ranged from Rs/kg 190.04 to 242.64. The incidence cost (IC) of the diets was not affected by the inclusion levels of protein or extraction method of cassava starch. However, Profit index was influenced by the dietary protein level but not affected by the starch source. The profit index was higher for diets with low protein (30\%) compared to diets with high protein level (37\%) (Table $6)$.

\section{Discussion}

The growth performance of fish was not affected by dietary protein level (30\% or $37 \%$ protein) or the extraction method of starch or starch level. The fact that growth performance in terms of ADG and SGR was not

Table 1. Formulation (g/100g) and proximate composition (\%), (dry weight basis) of experimental diets.

\begin{tabular}{|c|c|c|c|c|}
\hline Ingredients & $\mathrm{FM}_{25} \mathrm{R}_{17}$ & $\mathrm{FM}_{25} \mathrm{D}_{17}$ & $\mathrm{FM}_{15} \mathrm{R}_{25}$ & $\mathrm{FM}_{15} \mathrm{D}_{25}$ \\
\hline Fish meal & 25 & 25 & 15 & 15 \\
\hline Soybean meal & 35 & 35 & 36 & 36 \\
\hline Coconut meal & 17 & 17 & 17 & 17 \\
\hline Soybean oil & 2 & 2 & 3 & 3 \\
\hline Vitamin \& mineral mix & 3 & 3 & 3 & 3 \\
\hline Cassava starch (fresh root) & 17 & - & 25 & - \\
\hline Cassava starch(dry chips) & - & 17 & - & 25 \\
\hline $\mathrm{Cr}_{2} \mathrm{O}_{3}$ & 1 & 1 & 1 & 1 \\
\hline \multicolumn{5}{|l|}{ Proximate composition } \\
\hline Protein & 37.1 & 37.5 & 30.6 & 31.3 \\
\hline Lipid & 5.32 & 5.35 & 5.18 & 5.22 \\
\hline Carbohydrate & 36.01 & 35.99 & 41.33 & 41.3 \\
\hline Energy $(\mathrm{kJ})$ & 1534.95 & 1534.91 & 1521.94 & 1521.87 \\
\hline Protein: Energy(mgkJ-1) & 24.23 & 24.20 & 20.35 & 20.30 \\
\hline
\end{tabular}

$\mathrm{FM}_{25} \mathrm{R}_{17}$-Diet with $25 \mathrm{~g}$ fish meal and $17 \mathrm{~g}$ cassava starch extract from fresh root

$\mathrm{FM}_{25} \mathrm{D}_{17}$ - Diet with $25 \mathrm{~g}$ fish meal and $17 \mathrm{~g}$ cassava starch extract from dry chips

$\mathrm{FM}_{15} \mathrm{R}_{25}$ - Diet with $15 \mathrm{~g}$ fish meal and $25 \mathrm{~g}$ cassava starch extract from fresh root

$\mathrm{FM}_{15} \mathrm{D}_{25}$ - Diet with $15 \mathrm{~g}$ fish meal and $25 \mathrm{~g}$ cassava starch extract from dry chips

Energy level of the final diet was calculated based on the Digestible energy levels (16.72, 17.62 and $37.62 \mathrm{~kJ} / \mathrm{g}$ for protein, carbohydrate and lipid, respectively; Nasser et al., 2018). 
influenced by decreasing dietary protein level from $37 \%$ to $30 \%$ and concurrently increasing starch level from $17 \%$ to $25 \%$ in Nile tilapia fingerling, indicating that cassava starch can spare some protein when the dietary protein is low. Similar results were reported by Azaza et al. (2015) in which a satisfactory growth performance of 0 . niloticus was observed when the dietary protein reduced from 344 to $258 \mathrm{~g} / \mathrm{kg}$ while increasing starch from 163.5 to $401.3 \mathrm{~g} / \mathrm{kg}$. Comparable growth performance of Nile tilapia fish was observed for fish fed $16 \%$ of gelatinized cornstarch and $28 \%$ protein when compared to the control diet containing $35 \%$ of protein. (Maurice et al., 2018). Shiau and Peng (1993) found that decreasing dietary protein level from $28 \%$ to $24 \%$ by increasing the starch or dextrin content in the diet from $37 \%$ to $41 \%$ did not reduce weight gain of Nile tilapia. Wee and Ng (1986) mentioned that growth performance increased when the level of cassava root meal increased up to a maximum of $60 \%$ with a fixed level of $30 \%$ crude protein. It was pointed out that carbohydrate utilization in tilapia and catfish is affected by carbohydrate source, complexity and presence of carbohydrate-metabolizing enzymes (Rahman et al., 2017).

The condition factor greater than one suggests that the fish were in good health condition and indicates an isometric growth (Migiro et al, 2014). In the present study, the value of the condition factor for fish in all treatments was greater than one (1.67 \pm 0.02 $1.78 \pm 0.00)$, which indicated good health condition of the fish during the present study and indicated an isometric growth. Ighwela and Ahmed, (2011) stated that the mean condition factor $(\mathrm{K})$ for the $O$. niloticus was between 1.64-1.86 demonstrating good health condition and isometric growth.

The mean water quality parameters obtained in the experimental tanks did not vary significantly $(P>0.05)$ and all were within the suggested tolerance ranges. Fish health is mainly affected by water quality parameters of the environment in which fish live.

Table 2. Growth performance (mean \pm SE) of Nile tilapia fed the experimental diets.

\begin{tabular}{|c|c|c|c|c|c|c|c|}
\hline \multirow[t]{2}{*}{ Parameter } & \multicolumn{4}{|c|}{ Experimental diets } & \multicolumn{3}{|c|}{ Significance Level } \\
\hline & $\mathrm{FM}_{25} \mathrm{R}_{17}$ & $\mathrm{FM}_{25} \mathrm{D}_{17}$ & $\mathrm{FM}_{15} \mathrm{R}_{25}$ & $\mathrm{FM}_{15} \mathrm{D}_{25}$ & Protein & Starch & $\mathrm{P} \times \mathrm{S}$ \\
\hline Initia1Length $(\mathrm{cm})$ & $3.99 \pm 0.01$ & $4.02 \pm 0.07$ & $4.02 \pm 0.04$ & $4.09 \pm 0.05$ & ns & ns & ns \\
\hline Initial weight(g) & $1.11 \pm 0.05$ & $1.09 \pm 0.02$ & $1.11 \pm 0.02$ & $1.14 \pm 0.04$ & ns & ns & ns \\
\hline Final length $(\mathrm{cm})$ & $8.08 \pm 0.31$ & $8.23 \pm 0.08$ & $8.33 \pm 0.16$ & $8.21 \pm 0.16$ & ns & ns & ns \\
\hline Final weight(g) & $9.20 \pm 1.19$ & $9.31 \pm 0.29$ & $10.29 \pm 0.64$ & $9.36 \pm 0.67$ & ns & ns & ns \\
\hline ADG (\%) & $17.71 \pm 3.7$ & $18.0 \pm 0.95$ & $19.68 \pm 1.20$ & $17.32 \pm 2.24$ & ns & ns & ns \\
\hline SGR (\%) & $5.0 \pm 0.41$ & $5.11 \pm 0.11$ & $5.29 \pm 0.13$ & $5.0 \pm 0.26$ & ns & ns & ns \\
\hline $\mathrm{K}$ & $1.72 \pm 0.03$ & $1.67 \pm 0.02$ & $1.78 \pm 0.00$ & $1.68 \pm 0.02$ & ns & ns & ns \\
\hline $\mathrm{HSI}$ & $0.95 \pm 0.18$ & $0.93 \pm 0.11$ & $0.98 \pm 0.02$ & $1.01 \pm 0.09$ & ns & ns & ns \\
\hline VSI & $9.51 \pm 0.73$ & $8.35 \pm 1.5$ & $9.4 \pm 1.45$ & $8.48 \pm 0.66$ & ns & ns & ns \\
\hline $\begin{array}{l}\text { Food consumption } \\
\text { (\%BW/Day) }\end{array}$ & $10.61 \pm 0.25$ & $9.92 \pm 0.43$ & $11.09 \pm 0.35$ & $11.00 \pm 0.37$ & ns & ns & ns \\
\hline FCR & $1.47 \pm 0.29$ & $1.53 \pm 0.02$ & $1.45 \pm 0.05$ & $1.65 \pm 0.03$ & ns & ns & ns \\
\hline PER & $1.5 \pm 0.04$ & $1.64 \pm 0.11$ & $2.31 \pm 0.07$ & $2.02 \pm 0.03$ & $0.021 *$ & ns & ns \\
\hline Survival & $91.67 \pm 4.31$ & $80.56 \pm 5.56$ & $97.22 \pm 2.78$ & $88.89 \pm 2.78$ & ns & ns & ns \\
\hline
\end{tabular}

Means were evaluated using two-way ANOVA $(\mathrm{P}<0.05)$

ns - not significant

*** - significant at 0.05 level

ADG\% $=$ Initial weight (g)-Final weight (g)/ Initial weight (g) (Time period of expe.in days) $\times 100$

SGR\% $=(\ln ($ Final weight $(\mathrm{g}))-\ln ($ Initial weight $(\mathrm{g})) /$ Time period of experiment in days $\times 100$

Condition factor $(\mathrm{K})=($ Total weight $\times 100) /$ Total length3

HIS $=$ Liver weight $(\mathrm{g}) /$ Somatic Weight $(\mathrm{g}) \times 100$

$\mathrm{VSI}=$ Visceral Weight $(\mathrm{g}) /$ Somatic Weight $(\mathrm{g}) \times 100$

Food consumption $=$ Weight of feed consumed $(\mathrm{g}) /$ Weight of fish $(\mathrm{g}) \times 100$

$\mathrm{FCR}=$ Feed consumed $(\mathrm{g}) /$ Total wet weight gain $(\mathrm{g}) \times 100$

PER $=$ Total wet weight gain $(\mathrm{g}) /$ Protein intake $(\mathrm{g}) \times 100$

Survival $(\%)=($ Initial number of fish $) /($ Final number of fish $) \times 100$

Table 3 Apparent Digestibility Coefficient $(A D C)($ mean $\pm S E)$ of Nile tilapia fed experiment diets.

\begin{tabular}{|c|c|c|c|c|}
\hline Treatment & ADC dry matter & Protein & Starch & $\mathrm{P} \times \mathrm{S}$ \\
\hline $\mathrm{FM}_{25} \mathrm{R}_{17}$ & $83.56 \pm 0.02$ & & & \\
\hline $\mathrm{FM}_{25} \mathrm{D}_{17}$ & $83.57 \pm 0.15$ & $0.009 *$ & ns & ns \\
\hline $\mathrm{FM}_{15} \mathrm{R}_{25}$ & $84.77 \pm 0.27$ & & & \\
\hline $\mathrm{FM}_{15} \mathrm{D}_{25}$ & $84.97 \pm 0.23$ & & & \\
\hline
\end{tabular}


Maintaining the water quality parameters for fingerlings of Nile tilapia at optimum level is essential to avoid the stressful conditions of fish and to achieve best growth, feed conversion and survival (Masser et al., 1999). As most important limiting factor for fish kept in tanks, the concentration of ammonia for Nile tilapia should be less than $0.05 \mathrm{mg} / \mathrm{L}$, and optimum levels for temperature (22-28 OC), dissolved oxygen (5 mg/L), $\mathrm{pH}(7-8)$, Nitrate (should be less than $0.5 \mathrm{mg} / \mathrm{L}$ ) should be maintained (Siddiqui et al., 1989, Masser et al., 1999). The obtained water quality parameters during the experimental period in the present study were within the optimum range for tilapia culture.

The FCR obtained in current study (1.47-1.65) were comparable to values reported in previous studies on tilapia. Wee and Ng (1986) reported that good feed conversion ratios of tilapia were obtained in all diets with an average of 1.4. Azaza et al. (2015) reported that FCR values tended to increase from 1.5 to 1.7 with the decrease of dietary protein level while increasing starch level. FCR value depends on various factors like dietary protein level, protein quality, carbohydrate level, sex of fish, water quality and fish activity (Wee and Ng, 1986, Hasan and Khan, 2013).

PER was significantly increased with decreasing dietary protein level and that showed fish can efficiently utilize lower quantity of dietary protein while showing comparable growth in the present study. Sá et al. (2008) also stated that the protein efficiency ratio increased significantly as the dietary starch level increased, independently of the starch source. The results of this present study revealed that the fingerling Nile tilapia fed diets with cassava starch using two extraction methods exhibited good growth and showed better feed utilization even at the $25 \%$ (low) dietary protein level. When optimum carbohydrate level and protein level contain in the diet, it would reduce the cost of feed and mitigate the environmental impacts such as eutrophication occur due to excess nitrogen excretion (Azaza et al., 2015; Maurice et al., 2018).

Table 4. Whole-body proximate composition (\% Dry weight basis) (mean \pm SE) of Nile tilapia fed experimental diets.

\begin{tabular}{lcccccccc}
\hline Proximate & Initial body & \multicolumn{4}{c}{ Final body composition } & \multicolumn{3}{c}{ Significance Level } \\
\cline { 3 - 9 } composition & composition & $\mathrm{FM}_{25} \mathrm{R}_{17}$ & $\mathrm{FM}_{25} \mathrm{D}_{17}$ & $\mathrm{FM}_{15} \mathrm{R}_{25}$ & $\mathrm{FM}_{15} \mathrm{D}_{25}$ & Protein & Starch & $\mathrm{P} \times \mathrm{S}$ \\
\hline Moisture\% & $72.41 \pm 0.04$ & $73.08 \pm 0.26$ & $72.72 \pm 0.32$ & $73.61 \pm 0.43$ & $72.59 \pm 0.67$ & $\mathrm{~ns}$ & $\mathrm{~ns}$ & $\mathrm{~ns}$ \\
Protein\% & $57.9 \pm 0.24$ & $61.27 \pm 0.72$ & $59.7 \pm 0.36$ & $60.87 \pm 0.42$ & $61.50 \pm 0.57$ & $\mathrm{~ns}$ & $\mathrm{~ns}$ & $\mathrm{~ns}$ \\
Lipid\% & $9.13 \pm 0.11$ & $10.64 \pm 0.38$ & $10.95 \pm 0.32$ & $10.64 \pm 0.03$ & $10.30 \pm 0.34$ & $\mathrm{~ns}$ & $\mathrm{~ns}$ & $\mathrm{~ns}$ \\
Ash\% & $8.11 \pm 0.13$ & $8.91 \pm 0.55$ & $8.24 \pm 0.18$ & $8.26 \pm 0.05$ & $8.25 \pm 0.10$ & $\mathrm{~ns}$ & $\mathrm{~ns}$ & $\mathrm{~ns}$ \\
\hline
\end{tabular}

Means were evaluated using two-way ANOVA $(\mathrm{P}<0.05)$.

ns - not significant

$* * *$ - significant at 0.05 level

Table 5. Water quality parameters of experimental tanks.

\begin{tabular}{lccccccc}
\hline Parameters & \multicolumn{3}{c}{ Treatment } & \multicolumn{3}{c}{ Significance Level } \\
\cline { 2 - 7 } & $\mathrm{FM}_{25} \mathrm{R}_{17}$ & $\mathrm{FM}_{25} \mathrm{D}_{17}$ & $\mathrm{FM}_{15} \mathrm{R}_{25}$ & $\mathrm{FM}_{15} \mathrm{D}_{25}$ & \multicolumn{2}{c}{ Protein } & Starch \\
\hline Temperature $\left({ }^{\circ} \mathrm{C}\right)$ & $27.86 \pm 0.02$ & $27.82 \pm 0.03$ & $27.79 \pm 0.03$ & $27.76 \pm 0.04$ & $\mathrm{~ns}$ & $\mathrm{~ns}$ & $\mathrm{~ns}$ \\
$\mathrm{pH}$ & $6.77 \pm 0.14$ & $6.79 \pm 0.01$ & $6.79 \pm 0.05$ & $6.84 \pm 0.07$ & $\mathrm{~ns}$ & $\mathrm{~ns}$ & $\mathrm{~ns}$ \\
$\mathrm{DO}(\mathrm{mg} / \mathrm{L})$ & $5.89 \pm 0.11$ & $5.91 \pm 0.19$ & $5.92 \pm 0.07$ & $5.89 \pm 0.36$ & $\mathrm{~ns}$ & $\mathrm{~ns}$ & $\mathrm{~ns}$ \\
$\mathrm{NO}$ & $0.14 \pm 0.04$ & $0.15 \pm 0.04$ & $0.11 \pm 0.08$ & $0.13 \pm 0.04$ & $\mathrm{~ns}$ & $\mathrm{~ns}$ & $\mathrm{~ns}$ \\
$\mathrm{NO}^{3-}$ & $1.63 \pm 0.01$ & $1.63 \pm 0.01$ & $1.63 \pm 0.01$ & $1.67 \pm 0.07$ & $\mathrm{~ns}$ & $\mathrm{~ns}$ & $\mathrm{~ns}$ \\
$\mathrm{TAN}$ & 0 & 0 & 0 & 0 & - & - & - \\
\hline
\end{tabular}

Means were evaluated using two-way ANOVA $(\mathrm{P}<0.05)$.

ns - not significant

$* * *$ - significant at 0.05 level

Table 6. Economic analysis of experimental diets.

\begin{tabular}{|c|c|c|c|c|c|c|c|}
\hline \multirow[t]{2}{*}{ Experimental diet } & \multirow[t]{2}{*}{$\mathrm{FM}_{25} \mathrm{R}_{17}$} & \multirow[t]{2}{*}{$\mathrm{FM}_{25} \mathrm{D}_{17}$} & \multirow[t]{2}{*}{$\mathrm{FM}_{15} \mathrm{R}_{25}$} & \multirow[t]{2}{*}{$\mathrm{FM}_{15} \mathrm{D}_{25}$} & \multicolumn{3}{|c|}{ Significance Level } \\
\hline & & & & & Protein & Starch & $\mathrm{P} \times \mathrm{S}$ \\
\hline Total cost (Rs/kg) & 230.74 & 242.64 & 190.04 & 207.54 & - & - & - \\
\hline Incidence cost (IC) & $0.34 \pm 0.01$ & $0.41 \pm 0.01$ & $0.29 \pm 0.03$ & $0.33 \pm 0.00$ & ns & ns & ns \\
\hline Profit Index & $1.32 \pm 0.03$ & $1.29 \pm 0.01$ & $1.69 \pm 0.01$ & $1.73 \pm 0.02$ & $0.008^{*}$ & ns & ns \\
\hline
\end{tabular}

Total cost of feeds were calculated (market value of ingredients + estimated cost for preparation which was considered as Rs. $30 / \mathrm{kg}$ ).

Means were analyzed using two-way ANOVA $(P<0.05)$.

ns - not significant

*** - significant at 0.05 level 
Apparent digestibility coefficient (ADC) of dry matter was affected by dietary protein level in the present study. The highest ADC of dry matter was recorded for diets containing low protein level (30\% P) when compared with the diets containing high protein levels $(37 \% \mathrm{P})$. Digestibility is one of the most important aspects in evaluating the efficiency of feed ingredients. Degani et al., 1997 reported that diets with high ADC (for eg: 83.8\%) performed well and showed good growth performance of Cyprinus carpio. Amirkolaie et al. (2006) reported that inclusion level of starch effect the ADC of dry matter and at the high starch level (35.85\%) the Nile tilapia were reaching their maximal capacity to digest starch and absorb glucose. ADC of dry matter in experimental diets were varied from 81.35 to 85.45 (Amirkolaie et al., 2006) which was approximately similar to the results of present study. Herbivorous fish have higher ability to digest and absorb carbohydrate than carnivorous fish species, as the higher amylase activity in the digestive tracts of herbivorous fish species (Stone et al, 2003). The inclusion level of starch affected the total amount of feces produced by the fish and the lower amount of feces produced at the higher ADC of dry matter (Amirkolaie et al., 2006). Yeo et al. (2017) mentioned that ADC of dry matter significantly improved by processing (Cooking, extruding or gelatinization) the carbohydrate-rich ingredients.

After 42 days, crude lipid content of the carcass of fish was slightly increased when compared with that of the initial fish. Moses et al. (2018) reported similar results of proximate composition of body compared to present study. Maurice et al. (2018) indicated that whole-body protein and lipid content was significantly influenced by the starch content and that maximum whole-body protein and lipid content were obtained from fish fed with diet containing the highest gelatinized cornstarch levels (21\% and 31\%). Therefore, when increasing the starch level in formulated diets up to optimum level, it is not negatively effecting on the growth and whole-body proximate composition in Nile tilapia fingerlings.

In the present study protein to energy ratio (P: E) in diets were ranged from 20.3 to $24.23 \mathrm{~g} / \mathrm{MJ}$. When the experimental diet contains a high $\mathrm{P}$ : $\mathrm{E}$ ratio (high protein level), part of the protein utilized for energy and when the P: E ratio is low (low protein level) carbohydrate utilized for energy and protein used mainly for the growth performances and maintenance (Ali et al., 2008). Therefore, in the present study amount of protein used for energy was minimized by increasing dietary carbohydrate source which is a non-protein energy source. Haidar et al. (2018) also reported that protein sparing effect can be used to increase growth of fish and reduces nitrogen excretion. In the present study the fish exhibited similar growth and feed utilization at low dietary protein levels compared to high protein levels and it can be concluded that carbohydrate spare some protein when the dietary protein level is low or at sub optimum level. When fish meets the energy requirements for their basic metabolism and voluntary

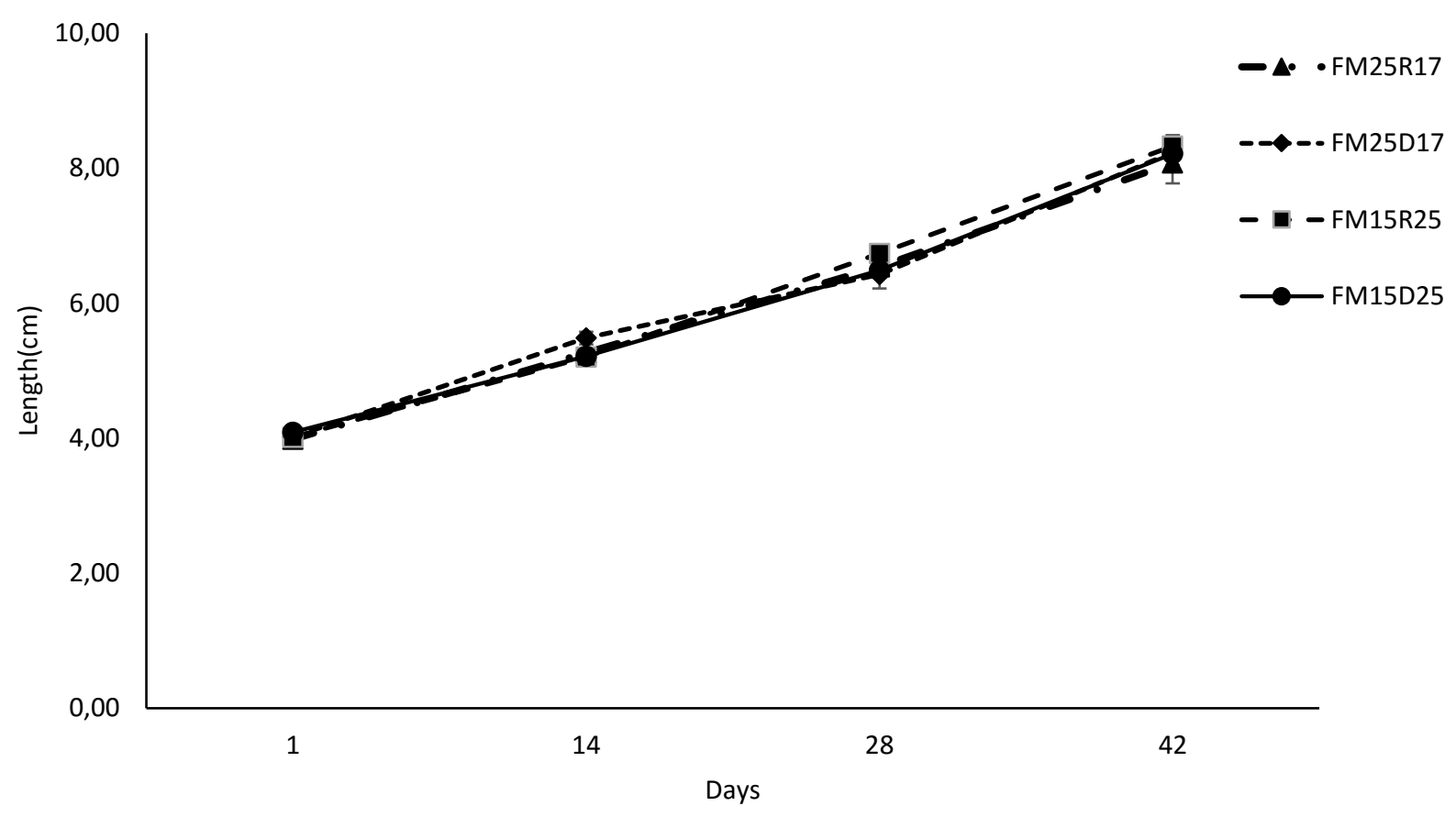

Figure 1. Mean $\pm \mathrm{SE}$ of total length of tilapia fish fed four experimental diets. $\left(\mathrm{FM}_{25} \mathrm{R}_{17}-25 \mathrm{~g}\right.$ fish meal, $17 \mathrm{~g}$ starch (fresh root), $\mathrm{FM}_{25} \mathrm{D}_{17}-25 \mathrm{~g}$ fish meal, $17 \mathrm{~g}$ starch (dry chips), $\mathrm{FM}_{15} \mathrm{R}_{25}-15 \mathrm{~g}$ fish meal, $25 \mathrm{~g}$ starch (fresh root), $\mathrm{FM}_{15} \mathrm{D}_{25}-15 \mathrm{~g}$ fish meal, $25 \mathrm{gstarch}$ (dry chips)). 
activities, fish usually use dietary protein for their growth (Lee et al., 2000). However, if there is excess protein (relation to energy) or dietary energy is low, protein act as an energy source. Thereby, excess energy may reduce feed consumption, disturb the proper utilization of other nutrient (Shiau and Peng, 1993). Azaza et al. (2015) reported that excess levels of starch significantly reduce the fish growth and feed utilization. Therefore, dietary protein and energy level must be balanced in the diet for maximum growth of fish.

Cost analysis revealed that, fish production in $\mathrm{FM}_{15} \mathrm{R}_{25}$ treatment is more profitable than other experimental treatments. $R$ starch prepared from fresh cassava is more profitable than $D$ starch prepared from dried cassava chips, as large amount of cassava fresh roots are required to prepare $D$ starch than $R$ starch. Therefore, the preparation of $D$ starch is expensive than preparation of $\mathrm{R}$ starch. The highest profit index was obtained by low protein diets due to the increase of the inclusion level of starch economic analysis indicated that the best profit index would be achieved by using $25 \% \mathrm{R}$ cassava starch in the diets for Nile tilapia fingerlings. Maurice et al. (2018) mentioned that compared to the diets containing $31 \%$ protein without starch, diets containing $31 \%$ gelatinized cornstarch and $21 \%$ of protein gelatinized cornstarch had the lowest costs. As fishmeal (FM) is the main protein source in fish feed formulation, research was focus on producing diets with low inclusion levels of FM or FM free diets in order to reduce the cost of the feed. Due to the limitations in reducing FM totally as it is difficult to find suitable alternative protein sources to replace FM very few aqua feeds produced with completely replacing fishmeal at present (Caldini et al., 2015; Simon et al., 2019). However, by utilizing carbohydrate source in fish feed preparation, fish meal dependence can be reduced as well as the feed cost can be reduced. Additionally, cassava is an unutilized source especially during harvesting season due to the excess production and farmers can get advantage by marketing this unutilized source for fish feed preparation.

This study demonstrated that the Nile tilapia fingerlings have the capability to utilize the carbohydrate and showed that Cassava starch can be effectively used to obtain optimal growth performances of tilapia. Economic profitability also increased by using higher starch level (25\% starch) while reducing the expensive fishmeal as cassava starch is cheaper than fishmeal. Therefore, the diets formulated to have lower protein level $(30 \%$ P) with $25 \%$ of cassava starch extracted from fresh root $\left(F M_{15} R_{25}\right)$ could be the best practical diet for Nile tilapia fingerlings among the tested diets. This diet allows to obtain growth performance similar to diets $\left(F M_{25} R_{17}\right.$ or $\left.F M_{25} D_{17}\right)$ containing $37 \%$ of higher protein level.

In the present study only two protein levels have been used to observe the protein sparing effect. Therefore, more investigations must be carried out by

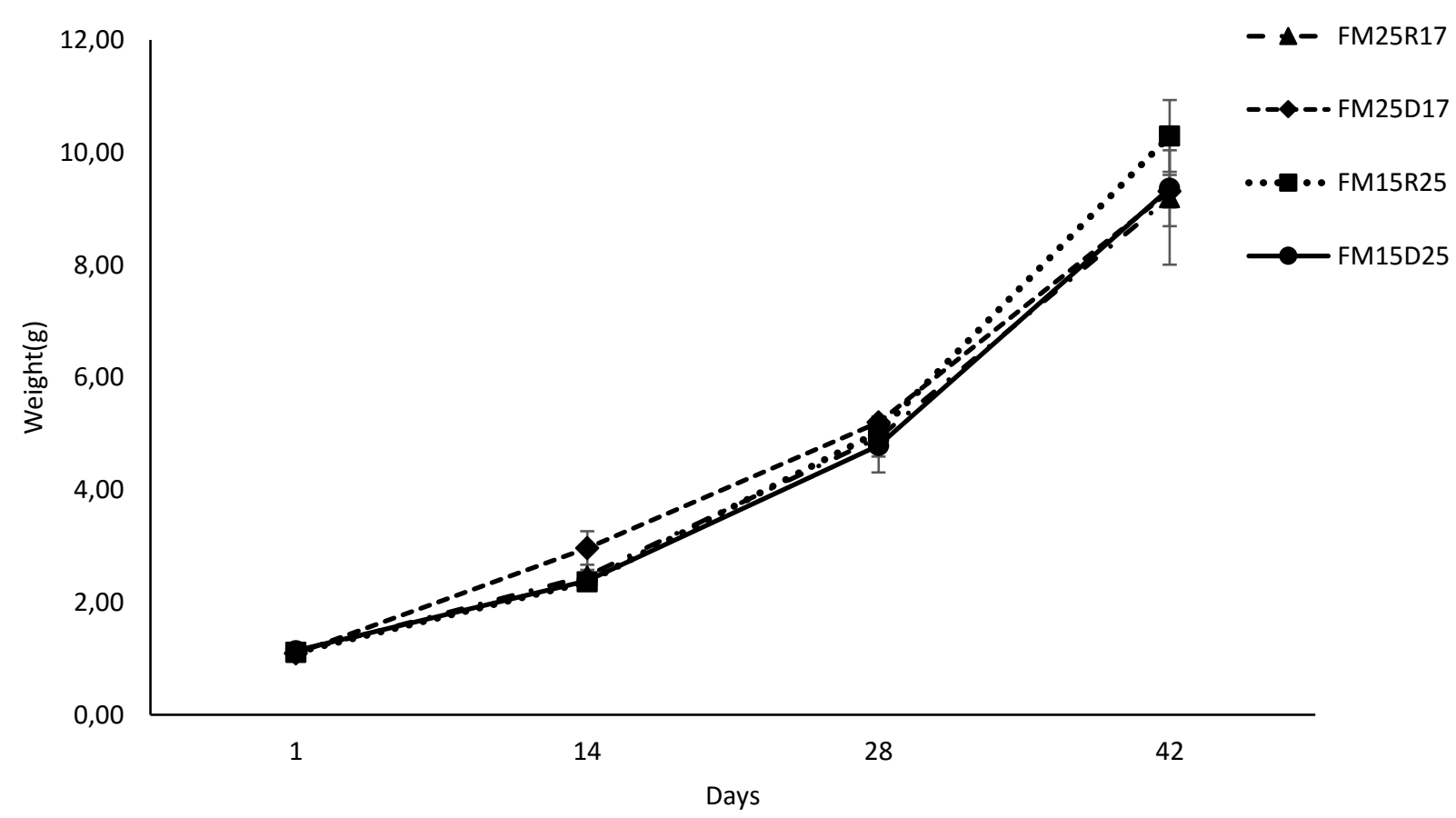

Figure 2. Mean $\pm \mathrm{SE}$ of total weight of tilapia fish fed four experimental diets. $\left(F M_{25} R_{17}-25 \mathrm{~g}\right.$ fish meal, $17 \mathrm{~g}$ starch (fresh root), $\mathrm{FM}_{25} \mathrm{D}_{17}-25 \mathrm{~g}$ fish meal, $17 \mathrm{~g}$ starch (dry chips), $\mathrm{FM}_{15} \mathrm{R}_{25}-15 \mathrm{~g}$ fish meal, $25 \mathrm{~g}$ starch (fresh root), $\mathrm{FM}_{15} \mathrm{D}_{25}-15 \mathrm{~g}$ fish meal, $25 \mathrm{gstarch}$ (dry chips)). 
altering the protein level and starch level to perceive the optimum protein to starch ratio for the Nile tilapia fingerlings. Further studies should be carried out to determine the long term effect of the dietary starch on proximate composition of the muscle of Nile tilapia.

\section{Ethical Statement}

The scientific and ethical responsibility of the animal experiment belongs to the author(s). ( ${ }^{* *}$ There is no committee established on the ethics in the university. However, fish were killed using MS222 anesthesia, and all efforts were made to minimize suffering.)

\section{Funding Information}

The author(s) received no specific funding for this work.

\section{Author Contribution}

Conceptualization: DM \& KR, Data Curation: DM \& $K R$, Formal Analysis: KR, Investigation: $D M$, Methodology: DM \& KR, Project Administration: KR, Resources: KR, Supervision: KR \& EH, Visualization: DM \& KR, Writing -original draft: $D M \& K R$, Writing -review and editing: $K R$.

\section{Conflict of Interest}

The author(s) declare that they have no known competing financial or non-financial, professional, or personal conflicts that could have appeared to influence the work reported in this paper.

\section{Acknowledgements}

The authors would like to thank the Department of Fisheries and Aquaculture for providing aquarium and laboratory facilities. Feed preparation, tanks and laboratory materials were provided by the grant received by KR (University of Ruhuna 2016 project - UGC Block Grant for strengthening research (RU/PG$\mathrm{R} / 16 / 10$ ) and was greatly acknowledged. Authors are thankful to Mr W.U.L Lanarolle and Mr Viraj Udayantha (Aquaculturists) for their guidance in fish husbandry.

\section{References}

Ali, A., Al-Ogaily, S.M., Al-Asgah, N.A., Goddard, J.S. \& Ahmed, S.I. (2008). Effect of feeding different protein to energy $(P / E)$ ratios on the growth performance and body composition of Oreochromis niloticus fingerlings. Journal of Applied Ichthyology, 24: 31-37. https://doi.org/10.1111/j.1439-0426.2007.00897.

Abera, S. \& Rakshit, S.K. (2003). Processing technology comparison of physicochemical and functional properties of cassava starch extracted from fresh root and dry chips, Starch-Stärke, 55: 287-296. https://doi.org/10.1002/star.200390072

Agbo, N.W. (2008). Oilseed meals as dietary protein sources for juvenile Nile tilapia (Oreochromis niloticus L.). PhD thesis. University of Stirling, UK. http://hdl.handle.net/1893/984.

Amarasinghe U.S. (2013). Fisheries resources in alleviation of hunger and malnutrition in Sri Lanka - accomplishment and challenges. Sri Lanka Journal of Aquatic Sciences 18: 1-15. doi: http://dx.doi.org/10.4038/sljas.v18i0.7034

Amirkolaie, A.K., Verreth, J.A. \& Schrama, J.W. (2006). Effect of gelatinization degree and inclusion level of dietary starch on the characteristics of digesta and faeces in Nile tilapia (Oreochromis niloticus (L.)), Aquaculture, 260: 194-205. https://doi.org/10.1016/j.aquaculture.2006.06.039.

AOAC, (1990). In: Official Methods of Analysis, 15th ed., Sec. 959.08. AOAC, Arlington, VA.

https://archive.org/details/ gov.law.aoac.methods.1.1990

Azaza, M.S., Khiari, N., Dhraief, M.N., Aloui, N., Kraïem, M.M. \& Elfeki, A. (2015). Growth performance, oxidative stress indices and hepatic carbohydrate metabolic enzymes activities of juvenile Nile tilapia, Oreochromis niloticus L., in response to dietary starch to protein ratios. Aquaculture research, 46: 14-27. https://doi.org/10.1111/are.12153.

Boonanuntanasarn, S., Jangprai, A., Kumkhong, S., PlagnesJuan, E., Veron, V., Burel, C., Marandel, L. \& Panserat, S. (2018). Adaptation of Nile tilapia (Oreochromis niloticus) to different levels of dietary carbohydrates: New insights from a long term nutritional study. Aquaculture, 496: 5865. https://doi.org/10.1016/j.aquaculture.2018.07.011.

Breuninger, W.F., Piyachomkwan, K. \& Sririth, K. (2009) Tapioca / Cassava Starch: Production and Use. Third Edit, In Starch. 541-568. Elsevier Inc. doi: 10.1016/B978-0-12746275-2.00012-4. https://doi.org/10.1016/B978-0-12746275-2.00012-4.

Caldini, N.N., Cavalcante, D.D.H., Rocha Filho, P.R.N. \& Sa, M.V.D.C. (2015). Feeding Nile tilapia with artificial diets and dried bioflocs biomass. Acta Scientiarum. Animal Sciences, 37: 335-341.

https://doi.org/10.4025/actascianimsci.v37i4.27043.

Degani, G., Viola, S. \& Yehuda, Y. (1997). Apparent digestibility coefficient of protein sources for carp, Cyprinus carpio L. Aquaculture Research, 28: 23-28. https://doi.org/10.1046/j.1365-2109.1997.00825.

FAO (2018) The State of World Fisheries and Aquaculture (SOFIA) | FAO | Food and Agriculture Organization of the United Nations. ISBN 978-92-5-130562-1 http://www.fao.org/3/i9540en/i9540en.pdf

FAO (2019) FAO: Nutritional requirements. (Accessed: 22 January 2019).

http://www.fao.org/fishery/affris/species-profiles/niletilapia/nutritional-requirements/en/

Fayose, F.T. \& Ogunlowo, A.S. (2012). The Search for High Quality and Affordable Fish Feed in Nigeria. In creating a competitive edge through agricultural mechanization and post-harvest technology in developing countries. International Conference of Agricultural EngineeringCIGRFAo-AgEng 2012: Agriculture and Engineering for a Healthier Life, Valencia, Spain, 8-12 July 2012.

Folch, J., Less, M. \& Stanley, G.S. (1957). A simple method for the isolation and purification of total lipid from animal tissues. Journal of Biological chemistry, 226:497-509. 
Furukawa, A. \& Tsukahara, H., (1966). On the acid digestion method for the determination of chromic oxide as an index substance in the study of digestibility in fish feed. Bulletin of the Japanese Society for the Science of fish, 35: 502-506.

Haidar, M.N., Bleeker, S., Heinsbroek, L.T.N. \& Schrama, J.W. (2018). Effect of constant digestible protein intake and varying digestible energy levels on energy and protein utilization in Nile tilapia. Aquaculture, 489: 28-35. https://doi.org/10.1016/j.aquaculture.2017.12.035.

Hasan, A.J.Z. \& Khan, U. (2013). Protein sparring effect and the efficiency of different compositions of carbohydrates, lipids and protein on the growth of rohu (Labeo rohita) fingerlings. World Journal of Fish Marine Science, 5: 244250.

https://doi.org/10.5829/idosi.wjfms.2013.05.03.7258.

Ighwela, K.A., Ahmed, A.B. \& Abol-Munafi, A.B. (2011). Condition factor as an indicator of growth and feeding intensity of Nile tilapia fingerlings (Oreochromis niloticus) feed on different levels of maltose. AmericanEurasian Journal of Agricultural and Environmental Science, 11: 559-563.

Lee, S.M., Cho, S.H. \& Kim, K.D. (2000). Effects of dietary protein and energy levels on growth and body composition of juvenile flounder Paralichthys olivaceus. Journal of the World Aquaculture Society, 31: 306-315. https://doi.org/10.1111/j.1749-7345.2000.tb00882.x

Masser, M.P., Rakocy, J., \& Losordo, T.M. (1999) Recirculating aquaculture tank production systems. Management of recirculating systems, SRAC publication 452. https://www.researchgate.net/publication/239549714

Maurice, Y.G., Célestin, B.M., Bédel, F., Olivier, E.A. \& Soumaila, D. (2018). Effects of modulation dietary gelatinized cornstarch/protein ratio on growth performance, feed utilization, and body composition of tilapia Oreochromis niloticus fingerlings. Journal of Applied Biology \& Biotechnology, 6:.31-36.

Meuser, F., Smolnik, H.D., Rajani, C. \& Giesemann, H.G. (1978). Comparison of starch extraction from tapioca chips, pellets and roots. Starch-Stärke, 30: 299-306. https://doi.org/10.1002/star.19780300904.

Migiro, K.E., Ogello, E.O. \& Munguti, J.M. (2014). The lengthweight relationship and condition factor of Nile tilapia (Oreochromis niloticus L.) broodstock at Kegati Aquaculture Research Station, Kisii, Kenya. International Journal of Advanced Research, 2: 777-782. http://www.journalijar.com

Montagnac, J.A., Davis, C.R. \& Tanumihardjo, S.A. (2009). Processing techniques to reduce toxicity and antinutrients of cassava for use as a staple food. Comprehensive Reviews in Food Science and Food Safety, 8: 17-27. https://doi.org/10.1111/j.1541-4337.2008.00064.x.

Moses, S., Agbaji, E.B., Ajibola, V.O. \& Gimba, C.E. (2018). Amino acid composition and proximate analysis in tilapia (Oreochromis mossambicus) fish from dams and rivers in Zamfara State, Nigeria. Journal of Applied Sciences and Environmental Management, 22: 899-905. https://doi.org/10.4314/jasem.v22i6.10.

Nasser, N., Abiad, M.G., Babikian, J., Monzer, S. \& Saoud, I.P. (2018). Using restaurant food waste as feed for Nile tilapia production. Aquaculture Research, 49:.31423150. https://doi.org/10.1111/are.13777.

Oke, O.L. (1994). Eliminating cyanogens from cassava through processing: Technology and tradition. In International workshop on Cassava Safety, 375: 163-174. http://doi.org/10.17660/ActaHortic.19994.375.14

Rahman, M.L., Salam, M.A. \& Ahsan, M.E. (2017). ProteinSparing Ability of Carbohydrates from Different Sources in Diets for Fry of Stinging Catfish Heteropneustes fossilis. Sains Malaysiana, 46: 239-244. http://dx.doi.org/10.17576/jsm-2017-4602-08.

Ricker, W.E. (1979). Growth rates and models. Fish physiology, pp.673-743.

https://www.academia.edu/699327/Fish_Physiology_1 979_Vol_08_Bioenergetics_and_Growth

Siddiqui, A.Q., Howlader, M.S, \& Adam, A.B (1989). Culture of Nile tilapia, Oreochromis niloticus (L.), at three stocking densities in outdoor concrete tanks using drainage water, Aquaculture Research, 20: 49-58. https://doi.org/10.1111/j.1365-2109.1989.tb00440.x

Sá, R., Pousão-Ferreira, P. \& Oliva-Teles, A. (2008). Effect of dietary starch source (normal versus waxy) and protein levels on the performance of white sea bream Diplodus sargus (Linnaeus) juveniles. Aquaculture Research, 39: 1069-1076. https://doi.org/10.1111/j.1365-2109.2008.01967.x.

Shiau, S.Y. \& Peng, C.Y. (1993). Protein-sparing effect by carbohydrates in diets for tilapia, Oreochromis niloticus $\times$ O. aureus. Aquaculture, 117: 327-334. https://doi.org/10.1016/0044-8486(93)90329-W.

Simon, C.J., Blyth, D., Fatan, N.A. \& Suri, S. (2019). Microbial biomass $\left(\right.$ Novacq $^{\mathrm{TM}}$ ) stimulates feeding and improves the growth performance on extruded low to zero-fishmeal diets in tilapia (GIFT strain). Aquaculture, 501: 319-324. https://doi.org/10.1016/j.aquaculture.2018.11.052.

Somendrika, MA.D., Wickramasinghe, I., Wansapala, M.A.J., \& Peris, S. (2016) Quantification of the material flow of raw cassava tubers processing for export market. European Journal of Academic Essays, 3: 105-108

Stone, D.A.J., Allan, G.L. \& Anderson, A.A. (2003). Carbohydrate utilization by juvenile silver perch, Bidyanus bidyanus (Mitchell). III. The protein-sparing effect of wheat starch-based carbohydrates. Aquaculture Research, 34: 123-134. https://doi.org/10.1046/j.1365-2109.2003.00774.x.

Ubalua, A.O. \& Ezeronye, O.U. (2008). Growth responses and nutritional evaluation of cassava peel based diet on tilapia (Oreochromis niloticus) fish fingerlings. Journal of Food Technology, 6: 207-213.

https://medwelljournals.com/abstract/?doi=jftech.200 8.207.213.

Ufodike, E.B.C. \& Matty, A.J. (1983). Growth responses and nutrient digestibility in mirror carp (Cyprinus carpio) fed different levels of cassava and rice. Aquaculture, 31: 4150. https://doi.org/10.1016/0044-8486(83)90256-9

Wang, W., Sun, J, Liu, C., \& Xue, Z. (2017) Application of immunostimulants in aquaculture: current knowledge and future perspectives, Aquaculture Research, 48: 123. https://doi.org/10.1111/are.13161.

Wee, K.L. \& Tuan, N.A. (1988). Effects of dietary protein level on growth and reproduction in Nile tilapia (Oreochromis niloticus). In The Second International Symposium on 
Tilapia in Aquaculture. Manila, Philippines: ICLARM. pp. 401-410

Wee, K.L. \& Ng, L.T. (1986). Use of cassava as an energy source in a pelleted feed for the tilapia, Oreochromis niloticus L. Aquaculture Research, 17:129-138. https://doi.org/10.1111/j.1365-2109.1986.tb00094.x
Yeo, G.M., Blé, M.C., Otchoumou, K.A., Dabonne, S., Yao, L.A. \& Etchian, A.O. (2017). Digestibility and growth performance in fingerlings of tilapia Oreochromis niloticus fed with diet containing high-carbohydrate ingredients. International Journal of Fisheries and Aquatic Studies, 5: 171-175. 